\title{
Morphology and Reproductive Biology of Two Hill Stream Cyprinids; Balitora Brucei and Psilorhynchus Balitora, From the Ranganadi River (India), with a Special Note to Their Conservational Threats
}

Gitartha Kaushik ( $\nabla$ gitarthakaushik@gmail.com )

Rangapara College https://orcid.org/0000-0001-7672-0707

Sabitry Bordoloi

Institute of Advanced Study in Science and Technology

\section{Research Article}

Keywords: Balitora brucei, Psilorhynchus balitora, Ranganadi, Biology, Gonado-somatic index, Assam, India

Posted Date: August 24th, 2021

DOl: https://doi.org/10.21203/rs.3.rs-729571/v1

License: (c) (i) This work is licensed under a Creative Commons Attribution 4.0 International License. Read Full License

Version of Record: A version of this preprint was published at Environmental Science and Pollution Research on November 20th, 2021. See the published version at https://doi.org/10.1007/s11356-02117411-8. 


\section{Abstract}

The Gray's stone loach Balitora brucei and balitora minnow Psilorhynchus balitora abound in the torrential water bodies of South East Asia. The current paper redescribes morphology based on the fresh collection. Specific parameters of reproductive biology on both the fishes have been studied for the first time. Both the species were adapted to the same ecological conditions of the river Ranganadi. Fish specimens were collected at fortnightly interval from the river in the Lakhimpur district of Assam, India. The detailed study includes morphological data analysed with Mann Whitney $\mathrm{U}$ test and specific reproductive parameters such as condition factor (K), gonado-somatic index (GSI), modified gonado somatic index (MGSI), and Dobriyal index (DI). Progressive development of the gonads were confirmed with dissection and histological study. Both the species are multiple breeders with prolonged reproductive seasons ranging from four to five months. Both the fishes are found to be migrants from upstream and a good number of individuals were recorded during the monsoon season, reflecting the sampling site as a breeding ground. During winter, the local people use various chemicals, piscicidal plants and electric instruments for fishing resulting in a steep decline in number of individuals for both the species. Moreover, effect of the NEEPCO dam is the evident on the decline of the ichthyofaunal diversity of the river.

\section{Introduction}

Proper knowledge of the reproductive biology of the fishes is fundamental from a conservation perspective and to manage the fishery resources. A thorough study on reproductive biology is a crucial aspect in fishery science to explain the variations in the level of populations and to make efforts to increase the amount of harvest (Azadi and Mamun, 2004). Individual vigor and population replenishment are pre-eminently dependent on successful reproduction (Donelson et al., 2014). Reproductive traits are vital in population studies to assess exploitation level and legislative management regulation (Kumari et al., 2020). The biological indices related to reproduction can signify how fish utilize environment and energetic resources (Khatun et al., 2019).

Information on the reproductive biology of the torrential fishes from NE India is very scanty and one of the causes being inaccessibility of their habitats. Balitora brucei Gray, 1830, and Psilorhynchus balitora (Hamilton, 1822); two torrential cyprinids were selected for the present investigation. Gray (1830) established the Genus Balitora by describing Balitora brucei as a type specimen (Chen et al., 2005). This species is found in the high gradient streams and riffles of South East Asia, and till now, a total of 21 species were described under this genus (Froese and Pauly 02 / 2019). Kottelat (1988) and Kottelat and Chu (1988) reviewed this genus and described three Balitorid genera; Balitora, Hemimyzon and Sinohomaloptera based on the number of maxillary barbels. They also proposed Sinohomaloptera as a junior subjective synonym of the genus Balitora. The characteristic features of these loaches are small and elongated dorso-ventrally flattened body, large and horizontally flattened paired fins, inferior mouth, covered jaws with horny sheath, rostral flap divided into three lobes, lips covered with one or two rows of papillae and one or two maxillary barbels at the corner of the mouth (Conway and Mayden, 2010). Except 
for studies related to adaptive modifications (Roberts, 1982; Singh and Bisht, 2017), and length-weight analysis (Kaushik and Bordoloi, 2017); no research has been done on the biology for this species. On the other hand, Nag and Bhattacharjee (1995) studied the development and function of the cone cell ellipsosomes for this fish. Locally known as Pakhna chata (Pakhna: rock; Chata: to lick) by the people of the tea tribes of Assam, this small indigenous fish is categorized under the near-threatened (NT) category (Britz, 2010) in IUCN.

Genus Psilorhynchus McClelland (Family: Psilorhynchidae) are the small indigenous fishes inhabiting the torrential streams of South East Asia. They differ from the rest of the Cyprinid fishes by a greater number of unbranched pectoral fin rays, pharyngeal bone with four teeth in one row, depressed head with snout rather spatulate and a greatly reduced air bladder (Sen, 1985; Nelson, 1994; Talwar and Jhingran, 1991; Jayaram, 1999). Psilorhynchus is the only genus of the family Psilorhynchidae occurring in the GangesBrahmaputra drainages in Northeastern India and its adjacent countries, found in the pebbly beds of small rapid-running streams at the base of hills, pools in the course of torrential streams and pools with muddy bed (Arunachalam and Muralidharan, 2008; Nebeshwar et al., 2007). He et al., 2008 studied the phylogenetic position of this enigmatic genus by analyzing the mitochondrial genome and recommended to include them in a separate sub-family of Cyprinidae. Conway, 2011 studied the osteology and phylogeny of this genus within the order Cypriniformes and described the osteology of $P$. sucatio in details. Later, Conway et al., 2014 established the shape of the swim bladder as a character for sexual dimorphism for this fish. From the molecular biology perspective also, Conway et al., 2015 studied the molecular systematics from nuclear and mitochondrial DNA sequence data. So far description of 28 species of Psilorhynchus are available in the literature (Froese and Pauly, 02 / 2019). Kaushik and Bordoloi (2017) studied the length weight relationship for this species. Recently Lin et al., 2021 studied the reproductive characteristics of Psilorhynchus homaloptera from lower Yarlung Zangbo river in Tibet. Locally known as Sil Kamura (Sil: rock; Kamura: to bite; as they attach to stones with the help of adhesive organ), this small indigenous fish is categorized under least concern (LC) category (Singh, 2010).

Both Balitora brucei and Psilorhynchus balitora are facing conservational threats due to environmental and anthropogenic stresses. Use of electronic gears, chemicals and piscicidal plants for fishing results in killing of the small indigenous fishes which are not targeted like $B$. brucei and $P$. balitora resulting in decline of their population.

For the current study, both the fish species were collected from the same habitat, Ranganadi in Lakhimpur district of Assam, India. Morphological study was done on the freshly collected samples so that minor variation if any gets recorded as biological parameters on these fishes has been studied for the first time from this remote geographical locality. Parameters related to reproductive biology for both the fishes such as condition factor (K), gonado-somatic index (GSI), modified gonado - somatic index (MGSI) and Dobriyal index (DI) were studied in the current investigation. Progressive development of the gonads were confirmed with dissection and histological study.

\section{Materials And Methods}




\section{Ethical statement}

The fishes studied in the present study are not protected under The Wildlife Protection Act, 1972 (Last amended in 2013), India and the samplings were done from outside of any protected area jurisdiction, and hence no sampling regulation exists. Fishes for the current investigation were collected from fish landing sites at regular intervals.

\section{Sample collection}

The present study comprises of the fishes collected for three years (March 2013 to March 2016) from Ranganadi River $\left(27^{\circ} 11 \rrbracket 11 \llbracket N, 094^{\circ} 3 \varangle 54 \llbracket E\right)$ in Lakhimpur district of Assam, India. For catching fishes, cast net of different mesh sizes $(50-100 \mathrm{~mm}$ ) were used. Fishes were preserved in 10\% Formaldehyde solution by giving an incision on the abdomen at the sampling sites and later transferred to $6-8 \%$ Formaldehyde solution for further analysis in the laboratory.

20 individuals from both the species were selected on the basis of their total length ( $T L)$. All the morphometric measurements were taken with a Vernier caliper (Mitutoyo) nearest to $0.05 \mathrm{~mm}$. Body weight (BW) was measured with a digital balance (Sartorius, BS-223 S Germany) nearest to $0.001 \mathrm{~g}$. Mann Whitney U test was performed following McKnight and Najab, 2010 to analyze sexual dimorphism if any.

Data on reproductive biology was analyzed using various statistical indices. Parameters like condition factor and relative condition factor were analyzed following Fulton, 1904 and Ricker, 1975 respectively. Size at first maturity was analyzed by percentage occurrence of the mature fish method in various size groups during the spawning season and was determined by plotting the percentage of mature fishes against their average lengths by following Hodgkiss and Mann, 1978. Length, at which $50 \%$ of fishes were found to be mature, was considered as the size at first maturity. Matured fishes ( $N=20$ / month) obtained from the analysis of size at first maturity were dissected out to record the reproductive indices like gonado-somatic index (GSI) and modified gonado somatic index (MGSI) following Nikolskii, 1963 and Dobriyal index by Dobriyal et al., 1999.

Ova diameter was analyzed under a light microscope with ocular micrometer following Clark, 1934 and confirmed by using IMAGE J software (Version 1.49). 20-80 oocytes from anterior, middle and posterior side of 5-7 ovaries showing maximum GSI (assuming more the GSI, more be the maturity of the oocytes) collected in each month were examined and measured.

Fecundity was estimated using selected matured ova of stage-IV by Gravimetric method (Lagler, 1956). Matured ovaries were taken out, length and weight were measured. Later, ova were preserved in $5 \%$ Formaldehyde solution for 2-3 weeks. Ova turn hard in formaldehyde and become easy for handling. Three sub-samples were separated from the anterior, middle and posterior region of the ovary. Oocytes from these three parts were placed on a watch glass to make it free from the connective tissues and counted under a light microscope. 
The sex ratio of the fishes was compared using the Chi-square test $(\chi 2)$ following Fisher, 1930.

For histological studies, fresh tissues from gonads were fixed in Bouin's solution for 24 hours. Later, tissues were washed with distilled water and dehydrated with alcohol $(30 \%, 50 \%)$ and preserved in $70 \%$ alcohol until further processing. Tissues were then passed through graded alcohol $70 \%, 90 \%$, and Absolute alcohol) and Xylene. Then they were embedded in Paraffin. Tissue sections were cut at $5 \mu \mathrm{m}$. Double staining method with Hematoxylin and Eosin were followed and mounted in DPX for further histological study.

\section{Results}

\section{Morphological analysis}

The morphometric measurements of 20 individuals' of B. brucei (Fig. 1: A, B, C) and P. balitora (Fig. 2: A, $B, C)$ are presented in the Table 1. Measurements of various body parts presented in these tables were studied in relation to the independent variable (SL) and the values are calculated in percentage of SL.

Apart from the structure of the anal opening; no other external morphological variation was noted between the sexes in both the species. Sexual dimorphism was statistically verified using Mann Whitney $\mathrm{U}$ test and found that the Body depth at anal origin for $B$. brucei and body width at the anal origin for $P$. balitora were the only differences (Table 2). Sexes of individual sample were further confirmed by dissection.

\section{Condition Factor (K)}

The mean $\mathrm{K}$ values were recorded as $0.729 \pm 0.04$ for males and $0.772 \pm 0.048$ for females of $B$. brucei while $1.000 \pm 0.0229$ and $1.035 \pm 0.027$ for male and females of $P$. balitora respectively. Females had a slightly higher condition value in comparison to the males for both the fishes. Condition factor $(K)$ was analyzed month wise and highest condition factor was recorded in April $(0.860 \pm 0.026)$ for females and November $(0.806 \pm 0.011)$ in males of $B$. brucei while January $(1.16 \pm 0.033)$ for females and December (1.11 \pm 0.046$)$ for males in $P$. balitora. In $B$. brucei, lowest condition factor for male was recorded in August $(0.651 \pm 0.06)$ and March $(0.711 \pm 0.02)$ for females while in $P$. balitora, month of July was recorded for both males $(0.85 \pm 0.018)$ and females $(0.86 \pm 0.02)$.

In B. brucei, analysis of modified condition factor $\left(\mathrm{K}_{\mathrm{f}}\right)$ revealed January as the best month for the males $(1.39 \pm 0.04)$ and September for the females $(4.77 \pm 0.24)$. Lowest $K_{f}$ was recorded in February for the males $(0.208 \pm 0.003)$ and December $(0.286 \pm 0.01)$ for the females.

In $P$. balitora, $\mathrm{K}_{\mathrm{f}}$ revealed October is the best month for the males $(2.52 \pm 0.05)$ and December for the females $(1.52 \pm 0.03)$. The lowest values were recorded in May for the males $(0.173 \pm 0.003)$ and February for the females $(0.103 \pm 0.001)$. 
The gonads are leaf-like paired structures separated from each other, occupying a large area in the abdominal cavity. In P. balitora female; the lobes are nearly equal and mature lobes are coiled by the alimentary canal. Mature ova are yellowish while the testes are yellowish white for both the fishes. In the current study, three reproductive indices; Gonado-somatic index (GSI), Modified gonado-somatic index (MGSI) and Dobriyal index (DI) were analyzed to determine the maturity as well as the spawning periods of the fishes.

Statistical analysis showed no significant differences between GSI and MGSI for both the fishes. Mean monthly gonado-somatic index were analyzed which revealed the fishes as multiple breeders. In $B$. brucei, maximum GSI was recorded in June $(7.38 \pm 0.42)$ for males and August $(15.77 \pm 2.46)$ for females. The second highest peak for female was observed in June (15.62 \pm 3.01$)$. Lowest GSI ( $0.021 \pm 0.003)$ was recorded in October for females and January for males $(0.213 \pm 0.051)$. Five months (April to August) of reproductive activeness was observed in $B$. brucei through GSI analysis (Figure: 3 ).

In the males of $P$. balitora, the GSI increased from January $(0.28 \pm 0.03)$ to April $(0.2 \pm 0.04)$, and a slow peak was observed in September $(0.24 \pm 0.02)$. In the females, GSI increased from December $(12.28 \pm$ 2.02) to March (10.31 \pm 0.89$)$, and two peaks were observed in August (9.24 \pm 3.5$)$ and October $(9.45 \pm$ 1.27). The decrease in GSI and MGSI for females' started from April to June and in September. The GSI pattern showed 4 months of prolonged reproductive activity in P. balitora (Fig. 4).

Analysis of $\mathrm{DI}$ in $B$. brucei from April $(0.813 \pm 0.09)$ to August $(0.889 \pm 0.05)$ was an indicator by the females for the attempt to spawn. The lowest DI was recorded in March $(0.008 \pm .0008)$ indicates the resting phase for the fish. In males, the highest DI $(0.533 \pm 0.02)$ was observed in June. This increase in DI from April to August was an indicator of the first attempts to spawn by males. DI for both males and females are presented in Fig. 3. In P. balitora males, DI ranged from 0.110 to 0.210 showing the highest peak in January $(0.21 \pm 0.00)$. D showed a slightly increasing trend from August $(0.14 \pm 0.00)$ to November $(0.17 \pm 0.00)$, and gradually decreased from April $(0.14 \pm 0.02)$ to July $(0.12 \pm 0.01)$. The increasing trend indicated the first attempt by the male fish to spawn in these months (Fig. 4). In females, maximum DI was seen in January $(0.771 \pm 0.02)$, falling until April $(0.350 \pm 0.05)$ indicated the attempt to spawn by the fish in these months. The lowest DI recorded in June $(0.266 \pm 0.03)$ indicating the resting phase of the females. Increasing trends of DI in July and August and decreasing trend in September exhibited a long period of spawning by this fish (Fig. 4).

Size at first maturity was estimated for $B$. brucei where $50 \%$ of the male fishes matured at the length of $54 \mathrm{~mm}$ and in female in was $64.2 \mathrm{~mm}$. For $P$. balitora males it was recorded as $51 \mathrm{~mm}$ and for females $58.6 \mathrm{~mm}$. (Fig. 5, 6).

Absolute fecundity of $B$. brucei varied from $2197(6.91 \mathrm{~cm}, 2.583 \mathrm{~g})$ to $58016(10.4 \mathrm{~cm}, 8.272 \mathrm{~g})$, with a mean of $14320 \pm 2316$. Relative fecundity varied from $826(7.06 \mathrm{~cm}, 2.822 \mathrm{~g})$ to $8643(7.19 \mathrm{~cm}, 2.904 \mathrm{~g})$ with a mean of $3027 \pm 402$. Whereas absolute fecundity recorded in $P$. balitora was from 731(TL-60.05 $\mathrm{mm}, \mathrm{BW}-2.349 \mathrm{~g}$ ) to 6154 (TL- $76.8 \mathrm{~mm}, \mathrm{BW}-4.994 \mathrm{~g}$ ) with a mean of $2537.70 \pm 1705.9$ while relative fecundity ranged from 327-1608 (822.43 \pm 397.1$)$. 
Histological studies of the gonads were done to confirm the prolonged reproductive activity of the fishes (Fig. 7, 8).

\section{Sex ratio}

After abdominal dissection of 427 specimens in B. brucei, 230 were identified as males and 197 as females with a calculated sex ratio of 1: 0.92 . While in $P$. balitora, out of 560 individuals, 302 were identified as males and 258 were females with a sex ratio of $1: 0.877$. For both the fishes the sex ratio was significantly different from the standard ratio of calculated value and hypothetical distribution i.e. $1: 1$.

\section{Discussion}

Studies on the detailed biology of most of the indigenous fishes from India are lacking including species of the genus Balitora and genus Psilorhynchus though a total of 21 and 28 species respectively has been described so far (Froese and Pauly, 08 / 2019). This study on the reproductive biology of $B$. brucei and $P$. balitora will be able to fill this gap.

Sexual dimorphism is not very prominent in a number of fishes. For those, abdominal dissection is the only way to confirm the sex. Sex differentiation in $B$. brucei and $P$. balitora was not easy in the field (Conway, 2011; Conway et al., 2014) due to absence of remarkable visible character on the specimen. To analyze the presence of any sexually dimorphic character statistically, a homogeneity test (Mann Whitney U test) was performed with the data recorded on 20 males and 20 female specimens. It was found that body depth in the anal region of the gravid female fishes of $B$. brucei and wider body in the anal region of the gravid female fishes of $P$. balitora showing sexual dimorphism during breeding. Applying this homogenity test, Bordoloi and Baishya (2006) analyzed the sexual dimorphism for Puntius ornatus and recorded the differences in body width, interorbital space and in the length of caudal peduncle between the sexes. Later, Bordoloi and Saha (2007) did a comparative study in Clupisoma montana, Clupisoma garua and Eutropiichthys vacha using the same homogeneity test. Conway, 2011 on the other hand studied the osteology of the genus Psilorhynchus and found that the architecture of the Weberian apparatus shows sexual dimorphism. Later Conway et al., 2014 again found that the structure of the swimbladder also exhibits sexual dimorphism in the Psilorhynchid fishes.

The populations of $B$. brucei and $P$. balitora showed an unbalanced sex ratio in Ranganadi River with females outnumbering and attaining larger size than in males. This difference in sex ratio could be due to various reasons like the sex growth rate, behavior and mortality (Gomes et al., 2011). But the ecological importance of sex ratio is still not fully explained (Gross, 2005).

Condition factor $(\mathrm{K})$ and the relative condition $(\mathrm{Kn})$ factor are the two important parameters of fish biology analysis that used to study the recent physical and biological circumstances and fluctuations due to interactions among feeding conditions, parasitic infections, physiological factors and to compare the condition within a given sample (Le Cren, 1951). The condition factor also reflects food availability and 
growth, but is variable and dynamic. Schneider et al., 2000, found that individual fish within the same sample may differ considerably, and the average condition of each population varies seasonally and yearly. In the current study, the $\mathrm{K}$ value in male and female fishes of both $B$. brucei and $P$. balitora shows different values (B. brucei, $0.729 \pm 0.04$ for males and $0.772 \pm 0.048$ for females; P. balitora, $1.000 \pm$ 0.0229 in male and $1.035 \pm 0.027$ in female). A similar result on different ' $K$ ' values between the sexes of two Cyprinids; Rasbora tawarensis and Poropuntius tawarensis from Indonesia was obtained by Muchlisin et al., 2010. It was observed that the " $K$ " value for $B$. brucei $<1$ and for $P$. balitora is $>1$. The ' $K$ ' values of $P$. balitora (in both the sexes) were higher than 1 indicating habitat suitability for the growth of the fish (George et al., 1985). Similar study by Barnham and Baxter, 1998 supports our findings. As per their opinion, $\mathrm{K}$ value might be influenced by the age of fish, sex, season, stages of maturation, the fullness of gut, type of food consumed, the amount of fat reserve and degree of muscular development. Analysis of relative condition (Kn) factor for $B$. brucei males show peak in July $(1.081 \pm 0.01)$ and in April $(1.01 \pm 0.02)$ in case of females. While in $P$. balitora, the maximum $\mathrm{Kn}(1.01 \pm 0.01)$ was recorded in May for male and April (1.005) for females. Our study supports the findings of George et al., 1985 who opines that if the value of the relative condition factor is more than 1 ; it indicates the general wellbeing of the fish. Our finding signifies that the habitat Ranganadi River is conducive for the growth of these two fishes.

Analyses of length-weight and length-length relationships of both the fishes show positive allometric growth with highly significant value, $\mathrm{P}<0.001$ (Kaushik and Bordoloi, 2017). In the present collection, the new maximum total length $(\mathrm{TL}=81 \mathrm{~mm})$ has been recorded for $P$. balitora.

The size at first maturity gives the average total length of a fish species in which $50 \%$ of the fishes attain the sexual maturity. It is well known that the maturity of a fish varies considerably among different populations of the same species, different species and also within the limit of a single population (Nikolskii, 1963; Hossain et al., 2012). In the case of B. brucei,size at first maturity was recorded as 54 $\mathrm{mm}$ for males and $64.2 \mathrm{~mm}$ for females. While in $P$. balitora, the size at first maturity for males was 51 $\mathrm{mm}$ and for females was $58.6 \mathrm{~mm}$. The data on size at first maturity exhibited that males attain maturity at a smaller size than the females. Similar results were obtained by Weyl and Booth, 1999 for the cyprinid fish Labeo cylindricus. Hossain et al., 2016 also obtained similar results for eight exotic species of Bangladesh.

A number of indices were used for assessing the reproductive pattern of a species. Gonado-somatic index (GSI) is known as the indicator of physiological activities of the gonads (Wang et al., 2013). The present study was based on macroscopic observation of the gonads, recording diameter of the oocyte and later confirmed with histological study. GSI revealed that the spawning mainly occurs from April to August in B. brucei and from November to March and July to August in P. balitora. It was observed that $B$. brucei prefers to breed in high water level and during rainfall. Moreover from April to August, there is rise in atmospheric as well as water temperature being monsoon as well as summer season. The peaks of GSI and $\mathrm{K}$ indicate an allocation of energy to somatic growth and reproduction (Gomes and Araujo, 2004). The minimum $\mathrm{K}$ was observed just after the spawning, when the fishes were heading to another 
spawning season. These kind of seasonal changes in $\mathrm{K}$ with minimum values recorded just after the spawning were observed by various fishery scientists (Bengtsson, 1993; Gomes et al., 2011). The GSI values recorded in females were higher than males signifying the seasonal development of gonads in the fish is more pronounced in females than in males. This kind of prolonged reproductive period was recorded for a loach Cobitis keyvani from Talar River of southern Caspian Sea basin by Mousavi et al., 2012. A similar study by Tsikliras et al., 2013 explained the monthly proportion of maturity stages for each sex which can be used as an indicator of the spawning season.

Estimation of fecundity is an indicator of the reproductive potential of the species. In the current investigation, both absolute fecundity $(14320 \pm 2316)$ and relative fecundity $(3027 \pm 402)$ for $B$. brucei was found to be higher than $P$. balitora $(2537.70 \pm 1705.9$ and $822.43 \pm 397.1)$. For this difference of range in fecundity, Bagenal, 1978 and Bagenal and Braum, 1978 stated that fecundity might vary among individuals of the same size and age.

Analysis of the sex ratio is very important from the conservation perspective. In the present study, the sex ratio of both $B$. brucei and $P$. balitora showed a significant deviation from 1:1, i.e. more males compared to the females. Dominance of males in most months was also reported in the Bengal loach Botia dario by Hussain et al., 2007 from Bangladesh and Das and Bordoloi, 2015 from Assam, India.

During the study a good number of samples were seen during monsoon season; which is the main breeding period for both the species reflecting the sampling sites as a breeding ground. But in the winter, a very less number were observed in the collections which reflect their local migratory behaviour from upstream to downstream during breeding period.

It was recorded during the period of investigation that local people use different types of fishing gears to catch the fishes from the river. As both the fishes are small in size, so their value as food fish is very less. As they inhabit running water with a high dissolved oxygen (DO), they are not suitable as ornamental fish.

Due to ecological and anthropogenic stress the number of these fishes are declining in natural habitats. It was found that local people use various fishing gears that result in eradication of non target species. Moreover techniques like electric fishing and use of chemicals for catching food fishes cause decline in small indigenous fishes that are not preferred food fishes. They also use the mixture of the leaf extract of Polygonum species, popularly known as "maanch" which is a piscicidal plant. During winter, when the water level goes down, this plant extract is applied in the downstream water that causes lowering of DO and eventually fishes acclimatized in high DO level float due to asphyxiation and they are collected.

A number of studies have mentioned the effect of dam in decline of indigenous fishes (Kingsford, 2001; Light and Marchetti, 2007; Mohite and Samant, 2013; and Sarkar et al., 2015). Periodic release of water by North Eastern Electric Power Corporation Limited (NEEPCO) was also recorded as a reason for the declining number of fishes in the Ranganadi river. During the release, water velocity forces the indigenous fishes to move along thereby causing instantaneous death and also there is adverse impact on the feeding and breeding of the surviving population. 


\section{Conclusions}

Present study gives a detailed account on morphology and reproductive biology of the Gray's stone loach Balitora brucei and balitora minnow Psilorhynchus balitora (Hamilton, 1822). The parameters recorded conclusively prove that both the fishes harbored in same ecological conditions of the river are multiple breeders with prolonged reproductive activity.

\section{Declarations}

\section{Ethical Approval:}

We have collected our samples from the local fishermen on the fish landing sites. As both the fishes are true hill stream fauna, they die within a few minutes after collection. We have collected those dead fishes and preserved in $10 \%$ formalin in the sampling sites and later transferred to $6-8 \%$ formalin for further study in the laboratory.

\section{Consent to participate:}

Not applicable

\section{Consent to publish}

Not applicable

\section{Authors Contribution}

Gitartha Kaushik made the collections, data analysis and prepared the manuscript. Sabitry Bordoloi is the Ph.D. Supervisor.

\section{Funding}

No funding was received for the study.

Competing Interest

Not applicable

\section{Availability of data and materials:}

The datasets used and/or analysed during the current study are available from the corresponding author.

\section{References}

1. Arunachalam M, Muralidharan M (2008) Description of a new species of the genus Psilorhynchus (Teleostei: Psilorhynchidae) from a Western Ghat stream in southern India. The Raffles Bulletin of 
Zoology.56: 405-414.

2. Azadi MA, Mamun A (2004) Reproductive biology of the cyprinid, Amblypharyngodon mola (Hamilton) from the Kaptai reservoir, Bangladesh. Pakistan Journal of Biological Sciences. 7(10): 1727-1729.

3. Bagenal T (1978) Eggs and early life history. In: Methods for Assessment of Fish Production in Fresh Waters, IBP Handbook No. 3 IBP Handbook No 33: 165 - 210.

4. Bagenal TB, Braum E (1978) Egg and early life history. Methods of assessment of fish production in freshwater. Blackwell Sci Publ Oxford 165-201.

5. Bengtsson A (1993) Seasonal variation of mass, condition and gonadosomatic index in four horn sculpin (Myoxocephalus quadricornis) with normal and malformed vertebrae in the Gulf of Bothnia. J. Fish Biol. 42: 265-278.

6. Britz R (2010) Balitora brucei. The IUCN Red List of Threatened Species 2010: e.T166923A6292318. http://dx.doi.org/10.2305/IUCN.UK.2010-4.RLTS.T166923A6292318.en Downloaded on 24 January 2020

7. Barnham C, Baxter A (1998) Condition factor. K, For Salmonid Fish. Fisheries Note, State of Victoria, Department of Primary Industries, 1

8. Bordoloi S, Baishya A (2006) Puntius ornatus a new record for the Brahmaputra drainage and the state of Assam. Zoos' Print Journal. 21: 2292 - 2294.

http://dx.doi.org/10.11609/JoTT.ZPJ.1441.2292-4

9. Bordoloi S, Saha S (2007) Record of Clupisoma montana (Hora) from Assam and comparative study with related species. J. Inland Fish. Soc. India. 39(2): 23-31.

10. Carvalho TB, Gonçalves-de-Freitas E (2008) Sex group composition, social interaction, and metabolism in the fish Nile tilapia. Brazilian Journal of Biology. 68(4): 807-812. http://dx.doi.org/10.1590/S1519-69842008000400015

11. Chen X-Y, Cui, G-H, Yang, J-X (2005) Balitora nantingensis (Teleostei: Balitoridae), a new hill stream loach from Salween drainage in Yunnan, southwestern China. The Raffles Bulletin of Zoology Suppl. 13: $21-26$.

12. Clark FN (1934) Maturity of the California sardine (Sardina caerulea), determined by ova diameter measurements. Calif. Div. Fish Game. Fishery Bulletin. 42: 1-49.

13. Conway KW (2011) Osteology of the South Asian genus Psilorhynchus MxClelland, 1839 (Teleostei: Ostariophysi: Psilorhynchidae), with investigation of its phylogenetic relationships within the order Cypriniformes. Zoological Journal of the Linnean Society. 163 (1): 50-154. https://doi.org/10.1111/j.1096-3642.2011.00698.x

14. Conway KW, Britz R, Shrestha J, Manimekalan A, Ruber L (2015) Molecular systematics of the Asian torrent minnows (Ostariophysi: Psilorhynchidae) inferred from nuclear and mitochondrial DNA sequence data. Journal of Zoological Systematics and Evolutionary Research. 53(1): 33-44. https://doi.org/10.1111/jzs.12090 
15. Conway KW, Britz R, Siegel DS (2014) Different on the inside: extreme swimbladder sexual dimorphism in the South Asian torrent minnows. Biology letters. 10 (7): 20140348. https://doi.org/10.1098/rsbl.2014.0348

16. Conway K, Mayden R (2010) Balitora eddsi, a new species of hillstream loach (Ostariophysi: Balitoridae) from Nepal. Journal of fish biology. 76: 1466-73. https://doi.org/10.1111/j.10958649.2010.02575.x

17. Costa S, Andrade R, Carneiro LA, Gonçalves E, Kotrschal K, Oliveira R (2011) Sex differences in the dorsolateral telencephalon correlate with home range size in blenniid Fish. Brain, behavior and evolution. 77: 55-64. https://doi.org/10.1159/000323668

18. Das MK, Bordoloi S (2015) Length-weight relationship and reproductive parameters of Botia dario (Hamilton, 1822) in Assam, India. Journal of Applied Ichthyology. 31(3): 571-573. https://doi.org/10.1111/jai.12745

19. Dobriyal A (1983) Bioecology of some coldwater fishes correlated with hydrobiology of the Mandakini and the Nayar. D. Phil Thesis Garhwal University 290pp.

20. Dobriyal A, Rautela K, Rautela, A (1999) Invention of a new index for the determination of sexual maturity in fishes. Uttar Pradesh Journal of Zoology. 19: 207-210.

21. Donelson JM, McCormick MI, Booth DJ, Munday PL (2014). Reproductive Acclimation to Increased water temperature in a tropical reef fish. Plos One. 9(5): e97223. https://doi.org/10.1371/journal.pone.0097223

22. Fisher RA (1930) The Genetical theory of Natural Selection. Oxford University Press, London, U.K.

23. Froese R, Pauly D (2019) FishBase World Wide web electronic publication. www.fishbase.org ( 08/2019) Accessed on 06/02/2020.

24. Fulton TW (1904) The rate of growth of fishes. Twenty-second Annual Report, Part III. Fisheries Board of Scotland, Edinburgh 141-241pp.

25. George J, Sharma A, Venkatshvaran, K, Sinha P, Venogopal G, Birader R (1985) Length - weight relationship and relative condition factor in Cirrhinus mrigala and Labeo rohita from a sewage-fed tank. The Annals of Zoology. 23: 79-90.

26. Gomes ID, Araujo FG, (2004) Influences of the reproductive cycle on condition of marine catfishes (Siluriformes, Ariidae) in a coastal area at southeastern Brazil. Environ. Biol. Fish 71: 341- 351.

27. Gomes ID, Araujo FG, Uehara W, Sales A (2011) Reproductive biology of the armoured catfish Loricariichthys castaneus (Castelnau, 1855) in Lajes reservoir, southern Brazil. J. Appl. Ichthyol. 27: $1322-1331$.

28. Gross MR (2005) The evolution of parental care. Q. Rev. Biol. 80: 37-45.

29. He S, Gu X, Mayden RL, Chen WJ, Conway KW, Chen Y (2008) Phylogenetic position of the enigmatic genus Psilorhynchus (Ostariophysi: Cypriniformes): evidence from the mitochondrial genome. Molecular Phylogenetics and Evolution. 47: 419-425. https://doi.org/10.1016/j.ympev.2007.10.012 30. Hodgkiss IJ, Mann SH (1978) Reproductive biology of Sarotherodon mossambicus. 
31. Hossain MY, Hossen MA, Islam MM, Pramanik MN, Nawer F, Paul AK, Hameed HA, Rahman MM, Kaushik G, Bardoloi S (2016) Biometric indices and size at first sexual maturity of eight alien fish species from Bangladesh. The Egyptian Journal of Aquatic Research 42(3): 331-339. https://doi.org/10.1016/j.ejar.2016.09.001

32. Hossain M, Rahman MM, Miranda R, Leunda P, Oscoz J, Jewel M, Naif A, Ohtomi J (2012) Size at first sexual maturity, fecundity, length-weight and length-length relationships of Puntius sophore (Cyprinidae) in Bangladeshi waters. Journal of Applied Ichthyology. 28: 818-822. https://doi.org/10.1111/j.1439-0426.2012.02020.x

33. Hussain MA, Khatun MR, Hossain, MA (2007) On the fecundity and sex-ratio of Botia dario (Hamilton) (Cypriniformes: Cobitidae). University Journal of Zoology, Rajshahi University. 26: 27-29.

34. Illkyaz AT, Metin G, Soykan O, Kinacigil HT (2018) Spawning season, first maturity length and age of 21 fish species from the Central Aegean Sea, Turkey. Turkish Journal of Fisheries And Aquatic Sciences. 18(1): 211-216. https://doi.org/10.4194/1303-2712-v18_1_24

35. IUCN (2020) The IUCN Red List of Threatened Species. Accessed on $02^{\text {nd }}$ May 2020.

36. Jayaram KC (1999) The freshwater fishes of the Indian region. Narendra Publishing House, Delhi, $551 \mathrm{pp}$.

37. Kaushik G, Bordoloi S (2017) Length-weight and length-length relationships of Balitora brucei Gray, 1830 and Psilorhynchus balitora (Hamilton, 1822) from the Ranganadi River of Assam, India. Journal of Applied Ichthyology 33(6), 1301 - 1302. https://doi.org/10.1111/jai.13477

38. Khatun D, Hossain MY, Nawer F, Mostafa AA, Al-Askar AA (2019) Reproduction of Eutropiichthys vacha (Schilbeidae) in the Ganges river (NW Bangladesh) with special reference to potential influence of climate variability. Environmental Science and Pollution Research. 26: 10800-10815. https://doi.org/10.1007/s11356-019-04523-5

39. Kingsford RT (2000) Ecological impacts of dams, water diversions and river management on floodplain wetlands in Australia. Austral Ecology. 25 (2): 109-127. https://doi.org/10.1046/j.14429993.2000.01036.x

40. Kottelat M (1988) Two species of cavefishes from northern Thailand in the genera Nemacheilus and Homaloptera (Osteichthyes: Homalopteridae). Records of the Australian museum. 40: 225-231. https://doi.org/10.3853/j.0067-1975.40.1988.156

41. Kottelat M, Chu XL (1988) Revision of Yunnanilus with description of a miniature species flock and six new species from China (Cypriniformes: Homalopteridae). Environ. Biol. Fish. 23(1/2): 65-93. https://doi.org/10.1007/BF00000739

42. Kumari S, Sarkar UK, Karnatak G, Mandhir SK, Lianthuamluaia L, Kumar V, Panda D, Puthiyotti M, Das BK (2020) Food selectivity and reproductive biology of small indigenous fish Indian river shad, Gudusia Chapra (Hamilton, 1822) in a large tropical reservoir. 28: 11040-11052. https://doi.org/10.1007/s11356-020-11217-w

43. Lagler KF (1956) Freshwater Fishery Biology. Second Ed. W.M.C. Brown Company, Dubuque, lowa, $421 \mathrm{pp}$. 
44. Le Cren E (1951) The length-weight relationship and seasonal cycle in gonad weight and condition in the perch (Perca fluviatilis). The Journal of Animal Ecology. 201-219.

45. Light T, Marchetti MP (2007) Distinguishing between invasions and habitat changes as drivers of diversity loss among California's freshwater fishes. Conservation Biology, 21(2): 434-446. https://doi.org/10.1111/j.1523-1739.2006.00643.x

46. Lin P, Hu H, Liu F, Li M, Liu H (2021) Reproductive characteristics of Psilorhynchus homaloptera Hora and Mukerji, 1935 (Cyprinidae: Psilorhynchidae) in the lower Yarlung Zangbo River, Tibet. Journal of Oceanology and Limnology, 1-10.

47. McKnight PE, Najab J (2010) Mann-Whitney U Test. Corsini Encyclopedia of Psychology. https://doi.org/10.1002/9780479216.corpsy0524

48. Mohite SA, Samant JS (2013) Impact of environemental change on fish and fisheries in Warna river basin, Western Ghats, India. International Research Journal of Environemental Science. 2(6): 61-70.

49. Mousavi SH, Kamali A, Soltani M, Bani A, Esmaeili HR, Khoshbavar RH, Vatandoust S, Moradkhani Z (2012) Reproductive biology of Cobitis keyvani (Cobitidae) from the Talar River in the southern Caspian Sea basin. Iranian Journal of Fisheries Sciences. 11(2): 83 - 393. https://doi.org/10.1.1.861.4969\&rep=rep1\&type=pdf

50. Muchlisin ZA, Musman M, Azizah S (2010) Length-weight relationships and condition factors of two threatened fishes, Rasbora tawarensis and Poropuntius tawarensis, endemic to Lake Laut Tawar, Aceh Province, Indonesia. Journal of Applied Ichthyology. 26(6): 949-953. https://doi.org/10.1111/j.1439-0426.2010.01524.x

51. Nag TC, Bhattacharjee J. 1995. Retinal ellipsosomes: morphology, development, identification and comparison with oil droplets. Cell Tissue Res. 279: 633- 637 https://doi.org/10.1007/BF00318176

52. Nebeshwar K, Bagra K, Das D (2007) A new species of the cyprinoid genus Psilorhynchoides Yazdani et al.(Cypriniformes: Psilorhynchidae) from Arunachal Pradesh, India. Zoo's Print Journal 22: 26322636. https://doi.org/10.11609/JoTT.ZPJ.1634.2632-6

53. Nelson JS (1994) Fishes of the World 3rd Edition 600 pp. New YorkNikolskii G (1963) The ecology of fishes 352pp. London.

54. Ricker WE (1975) Computation and interpretation of biological statistics of fish populations. Department of Environment, Fisheries and Marine Service $382 \mathrm{pp}$.

55. Roberts TR (1982) Unculi (Horny Projections Arising from Single Cells), an Adaptive Feature of the Epidermis of Ostariophysan Fishes. Zoologica Scripta. 11(1): 55-76 https://doi.org/10.1111/j.14636409.1982.tb00518.x

56. Sarkar UK, Sharma J, Mahapatra BK (2015) A review of the fish communities in the Indian reservoirs and enhancement of fisheries and aquatic environement. Journal of Aquaculture Research \& Development. 6(1): 1

57. Schneider JC, Laarman PW, Howard Gowing JC, Laarman P, Gowing H (2000) Length-weight relationships. Manual of Fisheries Survey methods II: with periodic updates. Michigan department of Natural Resources, Fisheries Special Report. 25. Ann Arbar. Chapter 17: 1 - 16. 
58. Sen, TK (1985) The fish fauna of Assam and neighbouring North Eastern states of India. Records of Zoological Survey of India Occasional paper 64: 216 pp.

59. Singh, L.K. 2010. Psilorhynchus balitora. The IUCN Red List of Threatened species:

e.T168413A6487699. Downloaded on 02 May 2020. http://dx.doi.org/10.2305/IUCN.UK.20104.RLTS.T168413A6487699.en.

60. Singh H, Bisht I (2017) Comparative ultrastructural study of general body epidermis of the hill stream fishes; Botia almorhae (Teleosti: Botiidae), Homaloptera brucei (Teleostei: Balitoridae) and Schizothorax richardsonii (Teleostei: Cyprinidae). Int. J. Aquat. Biol. 5(6):370-374.

61. Talwar PK, Jhingran AG (1991) Inland Fishes of India and adjacent countriesOxford and IBH Pub. Co. Pvt. Ltd, NewDelhi. Vol.1: iv + 1-542; vol.2: 543-1158.

62. Tsikliras AC, Stergiou KI, Froese R (2013) Editorial note on reproductive biology of fishes. Acta Ichthyologica et Piscatoria 43, 1-5. https://doi.org/10.3750/AIP2013.43.1.01

63. Vishwanath W, Manojkumar W (1995) Fishes of the Cyprinoid Genus Psilorhynchus McClelland from Manipur, India, with Description of a New Species. Japanese Journal of Icthyology. 42, 249-253. https://www.jstage.jst.go.jp/article/jji1950/42/3-4/42_3-4_249/_pdf

64. Wang R, Liu J, Yang, X, Lin C, Huang, B, Jin W, X Pan (2013) Biological response of high-back crucian carp (Carassius auratus) during different life stages to wastewater treatment plant effluent.

Environmental Science and Pollution Research. 20: 8612-8620. https://doi.org/10.1007\%2Fs11356013-1817-4

65. Weyl O L, AJ Booth (1999) On the life history of a cyprinid fish, Labeo cylindricus. Environmental Biology of Fishes. 55(3): 215-225. https://doi.org/10.1023/A:1007543319416

\section{Tables}


Table 1

Morphometric measurement (mm) of P. balitora and B. brucei (male and female) Except TL and SL, values are in percentage SL (\%SL). Upper lines depict the Mean values and standard deviation with range in brackets.

\begin{tabular}{|c|c|c|c|c|c|}
\hline \multirow{3}{*}{$\begin{array}{l}\text { Sl. } \\
\text { No. }\end{array}$} & \multirow{3}{*}{$\begin{array}{l}\text { Morphometric } \\
\text { Parameters (mm) }\end{array}$} & \multicolumn{2}{|c|}{ Psilorhynchus balitora } & \multicolumn{2}{|l|}{ Balitora brucei } \\
\hline & & Male & Female & Male & Female $(n=20)$ \\
\hline & & $(n=20)$ & $(n=20)$ & $(n=20)$ & \\
\hline \multirow[t]{2}{*}{1.} & Total Length (TL) & $\begin{array}{l}65.05 \pm \\
7.51\end{array}$ & $\begin{array}{l}62.24 \pm \\
5.08\end{array}$ & $\begin{array}{l}70.18 \pm 8.09 \\
(60.25-89.05)\end{array}$ & $\begin{array}{l}82.88 \pm 12.20 \\
(66.2-100.2)\end{array}$ \\
\hline & & $\begin{array}{l}(51.05- \\
79.45)\end{array}$ & $\begin{array}{l}(54.9- \\
70.5)\end{array}$ & & \\
\hline \multirow[t]{2}{*}{2.} & Standard Length (SL) & $\begin{array}{l}54.02 \pm \\
6.30\end{array}$ & $\begin{array}{l}51.95 \pm \\
4.24\end{array}$ & $\begin{array}{l}58.62 \pm 6.91(49.7- \\
74.9)\end{array}$ & $\begin{array}{l}69.77 \pm 10.29 \\
(56.1-84.55)\end{array}$ \\
\hline & & $\begin{array}{l}(43.4- \\
65.6)\end{array}$ & $(46.1-59)$ & & \\
\hline \multirow[t]{2}{*}{3.} & Body Depth & $\begin{array}{l}19.21 \pm \\
1.62\end{array}$ & $\begin{array}{l}18.42 \pm \\
2.02\end{array}$ & $\begin{array}{l}12.36 \pm 1.05 \\
(10.31-13.23)\end{array}$ & $\begin{array}{l}13.96 \pm 1.16 \\
(11.40-15.49)\end{array}$ \\
\hline & & $\begin{array}{l}(16.45- \\
21.7)\end{array}$ & $\begin{array}{l}(15.69- \\
21.64)\end{array}$ & & \\
\hline \multirow[t]{2}{*}{4.} & Body Width & $\begin{array}{l}8.61 \pm \\
0.31\end{array}$ & $\begin{array}{l}8.72 \pm \\
0.69\end{array}$ & $\begin{array}{l}9.98 \pm 0.71(8.71- \\
11.01)\end{array}$ & $\begin{array}{l}8.63 \pm 0.69(7.87- \\
9.80)\end{array}$ \\
\hline & & $\begin{array}{l}(8.03- \\
9.14)\end{array}$ & $\begin{array}{l}(7.62- \\
10.19)\end{array}$ & & \\
\hline \multirow[t]{2}{*}{5.} & Head Depth & $\begin{array}{l}13.83 \pm \\
1.05\end{array}$ & $\begin{array}{l}13.96 \pm \\
1.09\end{array}$ & $\begin{array}{l}8.99 \pm 0.53(8.24- \\
10.01)\end{array}$ & $\begin{array}{l}9.27 \pm 0.48(8.56- \\
9.84)\end{array}$ \\
\hline & & $\begin{array}{l}12.24- \\
15.01\end{array}$ & $\begin{array}{l}(12.56- \\
15.45)\end{array}$ & & \\
\hline \multirow[t]{2}{*}{6.} & Head Length & $\begin{array}{l}20.47 \pm \\
1.43\end{array}$ & $\begin{array}{l}21.26 \pm \\
0.86\end{array}$ & $\begin{array}{l}20.55 \pm 0.83 \\
(19.82-21.93)\end{array}$ & $\begin{array}{l}20.54 \pm 0.82 \\
(19.13-21.74)\end{array}$ \\
\hline & & $\begin{array}{l}(17.8- \\
21.74)\end{array}$ & $\begin{array}{l}(19.5- \\
22.83)\end{array}$ & & \\
\hline \multirow[t]{2}{*}{7.} & Head Width & $\begin{array}{l}15.54 \pm \\
1.05\end{array}$ & $\begin{array}{l}15.57 \pm \\
0.911\end{array}$ & $\begin{array}{l}16.98 \pm 0.83 \\
(15.12-17.76)\end{array}$ & $\begin{array}{l}17.78 \pm 0.85 \\
(16.35-19.25)\end{array}$ \\
\hline & & $\begin{array}{l}(13.29- \\
16.71)\end{array}$ & $\begin{array}{l}(14.08- \\
17.11)\end{array}$ & & \\
\hline \multirow[t]{2}{*}{8.} & Eye Diameter & $\begin{array}{l}6.28 \pm \\
0.51\end{array}$ & $\begin{array}{l}6.60 \pm \\
0.405\end{array}$ & $\begin{array}{l}3.09 \pm 0.36(2.53- \\
3.86)\end{array}$ & $\begin{array}{l}2.86 \pm 0.42(2.31- \\
3.52)\end{array}$ \\
\hline & & $\begin{array}{l}(5.71- \\
7.11)\end{array}$ & $\begin{array}{l}(6.1- \\
7.48)\end{array}$ & & \\
\hline
\end{tabular}




\begin{tabular}{|c|c|c|c|c|c|}
\hline \multirow{3}{*}{$\begin{array}{l}\text { Sl. } \\
\text { No. }\end{array}$} & \multirow{3}{*}{$\begin{array}{l}\text { Morphometric } \\
\text { Parameters (mm) }\end{array}$} & \multicolumn{2}{|c|}{ Psilorhynchus balitora } & \multicolumn{2}{|l|}{ Balitora brucei } \\
\hline & & Male & Female & Male & Female $(n=20)$ \\
\hline & & $(n=20)$ & $(n=20)$ & $(n=20)$ & \\
\hline \multirow[t]{2}{*}{9.} & Snout Length & $\begin{array}{l}7.69 \pm \\
0.75\end{array}$ & $\begin{array}{l}8.42 \pm \\
0.65\end{array}$ & $\begin{array}{l}9.48 \pm 0.43(8.74- \\
9.95)\end{array}$ & $\begin{array}{l}9.58 \pm 0.30(9.21- \\
10.07)\end{array}$ \\
\hline & & $\begin{array}{l}(6.56- \\
8.73)\end{array}$ & $\begin{array}{l}(7.36- \\
8.85)\end{array}$ & & \\
\hline \multirow[t]{2}{*}{10.} & Inter Orbital Space & $\begin{array}{l}8.40 \pm \\
0.60\end{array}$ & $\begin{array}{l}8.41 \pm \\
0.61\end{array}$ & $\begin{array}{l}8.17 \pm 0.44(7.29- \\
9.05)\end{array}$ & $\begin{array}{l}8.24 \pm 0.42(7.66- \\
8.87)\end{array}$ \\
\hline & & $\begin{array}{l}(7.65- \\
9.41)\end{array}$ & $\begin{array}{l}(7.28- \\
9.11)\end{array}$ & & \\
\hline \multirow[t]{2}{*}{11.} & Pre Dorsal Length & $\begin{array}{l}46.65 \pm \\
1.51\end{array}$ & $\begin{array}{l}47.24 \pm \\
2.84\end{array}$ & $\begin{array}{l}43.59 \pm 2.74 \\
(36.37-45.89)\end{array}$ & $\begin{array}{l}43.79 \pm 0.83 \\
(42.53-45.39)\end{array}$ \\
\hline & & $\begin{array}{l}(44.24- \\
48.39)\end{array}$ & $\begin{array}{l}(43.62- \\
52.36)\end{array}$ & & \\
\hline \multirow[t]{2}{*}{12.} & Post Dorsal Length & $\begin{array}{l}76.12 \pm \\
2.43\end{array}$ & $\begin{array}{l}75.75 \pm \\
2.51\end{array}$ & $\begin{array}{l}75.93 \pm 1.62 \\
(73.34-78.51)\end{array}$ & $\begin{array}{l}77.41 \pm 1.56 \\
(75.11-79.90)\end{array}$ \\
\hline & & $\begin{array}{l}(72.25- \\
79.48)\end{array}$ & $\begin{array}{l}(71.69- \\
78.44)\end{array}$ & & \\
\hline \multirow[t]{2}{*}{13.} & Pre Pelvic distance & $\begin{array}{l}52.50 \pm \\
1.88\end{array}$ & $\begin{array}{l}52.57 \pm \\
2.18\end{array}$ & $\begin{array}{l}45.35 \pm 1.97 \\
(43.26-49.69\end{array}$ & $\begin{array}{l}45.20 \pm 1.95 \\
(42.01-48.98)\end{array}$ \\
\hline & & $\begin{array}{l}(50.04- \\
55.76)\end{array}$ & $\begin{array}{l}(49.46- \\
55.61)\end{array}$ & & \\
\hline \multirow[t]{2}{*}{14.} & Length of Dorsal fin & $\begin{array}{l}21.65 \pm \\
1.455\end{array}$ & $\begin{array}{l}21.24 \pm \\
1.02\end{array}$ & $\begin{array}{l}18.88 \pm 1.0(17.18- \\
20.12)\end{array}$ & $\begin{array}{l}19.21 \pm 0.83 \\
(17.55-20.42)\end{array}$ \\
\hline & & $\begin{array}{l}(18.78- \\
24.08)\end{array}$ & $\begin{array}{l}(19.31- \\
22.68)\end{array}$ & & \\
\hline \multirow[t]{2}{*}{15.} & $\begin{array}{l}\text { Length of base of } \\
\text { Dorsal fin }\end{array}$ & $\begin{array}{l}13.49 \pm \\
0.87\end{array}$ & $\begin{array}{l}13.61 \pm \\
0.75\end{array}$ & $\begin{array}{l}12.85 \pm 2.96(10.31 \\
-20.91)\end{array}$ & $\begin{array}{l}12.49 \pm 0.38 \\
(12.03-13.12)\end{array}$ \\
\hline & & $\begin{array}{l}(12.19- \\
15.04)\end{array}$ & $\begin{array}{l}(12.65- \\
14.67)\end{array}$ & & \\
\hline \multirow[t]{2}{*}{16.} & Length of Pectoral fin & $\begin{array}{l}18.59 \pm \\
1.38\end{array}$ & $\begin{array}{l}20.57 \pm \\
2.41\end{array}$ & $\begin{array}{l}13.40 \pm 0.74 \\
(11.73-14.16)\end{array}$ & $\begin{array}{l}16.06 \pm 0.84 \\
(14.08-17.08)\end{array}$ \\
\hline & & $\begin{array}{l}(16.92- \\
21.7)\end{array}$ & $\begin{array}{l}(17.01- \\
24)\end{array}$ & & \\
\hline
\end{tabular}




\begin{tabular}{|c|c|c|c|c|c|}
\hline \multirow{3}{*}{$\begin{array}{l}\text { Sl. } \\
\text { No. }\end{array}$} & \multirow{3}{*}{$\begin{array}{l}\text { Morphometric } \\
\text { Parameters (mm) }\end{array}$} & \multicolumn{2}{|c|}{ Psilorhynchus balitora } & \multicolumn{2}{|l|}{ Balitora brucei } \\
\hline & & Male & Female & Male & Female $(n=20)$ \\
\hline & & $(n=20)$ & $(n=20)$ & $(n=20)$ & \\
\hline \multirow[t]{2}{*}{17.} & Length of Pelvic fin & $\begin{array}{l}18.27 \pm \\
1.52\end{array}$ & $\begin{array}{l}16.30 \pm \\
5.82\end{array}$ & $\begin{array}{l}10.81 \pm 1.10(8.58- \\
12.67)\end{array}$ & $\begin{array}{l}13.74 \pm 0.97 \\
(11.89-14.97)\end{array}$ \\
\hline & & $\begin{array}{l}(15.63- \\
20.61)\end{array}$ & $\begin{array}{l}(16.25- \\
19.72)\end{array}$ & & \\
\hline \multirow[t]{2}{*}{18.} & $\begin{array}{l}\text { Depth of Caudal } \\
\text { Peduncle }\end{array}$ & $\begin{array}{l}8.29 \pm \\
1.02\end{array}$ & $\begin{array}{l}8.42 \pm \\
0.75\end{array}$ & $\begin{array}{l}6.57 \pm 0.51(5.94- \\
7.87)\end{array}$ & $\begin{array}{l}6.43 \pm 0.30(5.77- \\
6.80)\end{array}$ \\
\hline & & $(7-9.6)$ & $\begin{array}{l}(7.37- \\
9.44)\end{array}$ & & \\
\hline \multirow[t]{2}{*}{19.} & $\begin{array}{l}\text { Length of Caudal } \\
\text { Peduncle }\end{array}$ & $\begin{array}{l}15.69 \pm \\
1.05\end{array}$ & $\begin{array}{l}16.45 \pm \\
0.95\end{array}$ & $\begin{array}{l}20.17 \pm 1.33 \\
(18.52-22.36)\end{array}$ & $\begin{array}{l}18.76 \pm 1.26 \\
(16.04-19.96)\end{array}$ \\
\hline & & $\begin{array}{l}(13.62- \\
17.66)\end{array}$ & $\begin{array}{l}(15.22- \\
17.91)\end{array}$ & & \\
\hline \multirow[t]{2}{*}{20.} & $\begin{array}{l}\text { Length of longest fin } \\
\text { ray }\end{array}$ & $\begin{array}{l}21.65 \pm \\
1.45\end{array}$ & $\begin{array}{l}21.72 \pm \\
1.44\end{array}$ & $\begin{array}{l}19.23 \pm 1.08 \\
(17.18-20.84)\end{array}$ & $\begin{array}{l}19.44 \pm 0.62 \\
(18.72-20.42)\end{array}$ \\
\hline & & $\begin{array}{l}(18.78- \\
24.08)\end{array}$ & $\begin{array}{l}(19.7- \\
23.57)\end{array}$ & & \\
\hline \multirow[t]{2}{*}{21.} & Post orbital Length & $\begin{array}{l}5.50 \pm \\
0.92\end{array}$ & $\begin{array}{l}5.99 \pm \\
0.62\end{array}$ & $\begin{array}{l}6.09 \pm 0.30(5.54- \\
6.46)\end{array}$ & $\begin{array}{l}5.82 \pm 0.43(5.12- \\
6.38)\end{array}$ \\
\hline & & $\begin{array}{l}(3.54- \\
6.66)\end{array}$ & $\begin{array}{l}(5.41- \\
7.18)\end{array}$ & & \\
\hline
\end{tabular}


Table 2

Analysis of Mann Whitney U test to determine sexual dimorphism in P.balitora and $B$ brucei (* Value showing difference in between the sexes)

\begin{tabular}{|c|c|c|c|c|c|c|c|}
\hline \multirow[t]{2}{*}{ No. } & \multirow[t]{2}{*}{ Parameters } & \multicolumn{3}{|c|}{ Psilorhynchus balitora } & \multicolumn{3}{|c|}{ Balitora brucei } \\
\hline & & $\begin{array}{l}\text { U } \\
\text { Value }\end{array}$ & Z Value & P Value & $\begin{array}{l}\text { U } \\
\text { Value }\end{array}$ & Z Value & P Value \\
\hline 1. & Total Length (TL) & 40 & -0.08292 & 0.933915 & 19 & -1.06854 & -0.71472 \\
\hline 2. & Standard Length (SL) & 42 & 0.762862 & 0.445546 & 16 & -1.17195 & -0.75878 \\
\hline 3. & $\begin{array}{l}\text { Body depth (B.D.) at } \\
\text { anal origin }\end{array}$ & 30.5 & -0.16169 & 0.871547 & 56.85 & 2.3611 ** & 0.018219 \\
\hline 4. & $\begin{array}{l}\text { Body width (B.W) at } \\
\text { anal origin }\end{array}$ & 42 & $-6.69991 * \star$ & 2.08538 & 46 & -0.13788 & 0.890338 \\
\hline 5. & Head Depth (H.D.) & 47 & -0.02487 & 0.98015 & 13 & -1.27536 & 0.890338 \\
\hline 6. & Head Length (H.L.) & 46 & -0.03316 & 0.97354 & 9.5 & -1.396 & 0.162714 \\
\hline 7. & Head width (H.W.) & 48 & -0.01658 & 0.98676 & 10 & -1.37876 & 0.162969 \\
\hline 8. & Eye Diameter (E.D.) & 37 & -0.10779 & 0.91415 & 27 & -0.79279 & 0.4279 \\
\hline 9. & Snout Length (Sn.L.) & 41.5 & -0.07048 & 0.943810 & 13.5 & -1.25812 & 0.208348 \\
\hline 10. & $\begin{array}{l}\text { Inter Orbital Length } \\
\text { (I.O.L.) }\end{array}$ & 36.5 & -0.111941 & 0.91086 & 13.5 & -0.30266 & 0.381076 \\
\hline 11. & $\begin{array}{l}\text { Pre-Dorsal Length } \\
\text { (P.D.L.) }\end{array}$ & 46.5 & -0.02903 & 0.97684 & 14 & -0.29851 & 0.765313 \\
\hline 12. & $\begin{array}{l}\text { Post Dorsal Length } \\
\text { (Po.D.L.) }\end{array}$ & 31 & -0.157547 & 0.874813 & 13 & -0.3068 & 0.758993 \\
\hline 13. & $\begin{array}{l}\text { Pre Pelvic Distance } \\
\text { (P.P.D.) }\end{array}$ & 44 & -0.04975 & 0.96032 & 20 & -0.24876 & 0.803547 \\
\hline 14. & $\begin{array}{l}\text { Length of Dorsal Fin } \\
\text { Spine (L.D.F.S.) }\end{array}$ & 32.5 & -0.145109 & 0.884624 & 19 & -0.25705 & 0.797139 \\
\hline 15. & $\begin{array}{l}\text { Base of Dorsal Fin } \\
\text { (B.D.F.) }\end{array}$ & 46.5 & -0.029021 & 0.976847 & 24.5 & -0.21145 & 0.83254 \\
\hline 16. & Base of Anal fin (B.A.F.) & 21.5 & -0.236321 & 0.813183 & 8 & -0.34826 & 0.727643 \\
\hline 17. & $\begin{array}{l}\text { Length of Pectoral fin } \\
\text { Spine (L.P.F.S.) }\end{array}$ & 40.5 & -0.078773 & 0.93721 & 7.5 & -0.35241 & 0.724532 \\
\hline 18. & $\begin{array}{l}\text { Length of Pelvic fin } \\
\text { spine (L.Pe.F.S.) }\end{array}$ & 17.5 & -0.21166 & 0.83237 & 3 & -0.38972 & 0.696741 \\
\hline 19. & $\begin{array}{l}\text { Depth of Caudal } \\
\text { Peduncle (D.C.P.) }\end{array}$ & 41.5 & -0.07048 & 0.943810 & 19 & -0.25705 & 1 \\
\hline
\end{tabular}




\begin{tabular}{|c|c|c|c|c|c|c|c|}
\hline \multirow[t]{2}{*}{ No. } & \multirow[t]{2}{*}{ Parameters } & \multicolumn{3}{|c|}{ Psilorhynchus balitora } & \multicolumn{3}{|c|}{ Balitora brucei } \\
\hline & & $\begin{array}{l}\text { U } \\
\text { Value }\end{array}$ & Z Value & P Value & $\begin{array}{l}\text { Ualue } \\
\text { Val }\end{array}$ & Z Value & P Value \\
\hline 20. & $\begin{array}{l}\text { Length of Caudal } \\
\text { Peduncle (L.C.P.) }\end{array}$ & 49.5 & -0.004145 & 0.996691 & 34 & -0.13267 & 0.894453 \\
\hline 21. & $\begin{array}{l}\text { Length of Longest fin } \\
\text { Ray (L.L.F.R.) }\end{array}$ & 44 & -0.049718 & 0.96032 & 14.5 & -0.29437 & 0.768479 \\
\hline 22. & $\begin{array}{l}\text { Post Orbital Length } \\
\text { (P.O.L.) }\end{array}$ & 35 & -0.124379 & 0.901014 & 25.5 & -0.20315 & 0.839015 \\
\hline 23. & $\begin{array}{l}\text { Wide of Gap of Mouth } \\
\text { (W.G.M.) }\end{array}$ & 38 & -0.099503 & 0.920738 & 17.5 & -0.26949 & 0.787553 \\
\hline
\end{tabular}

Figures 

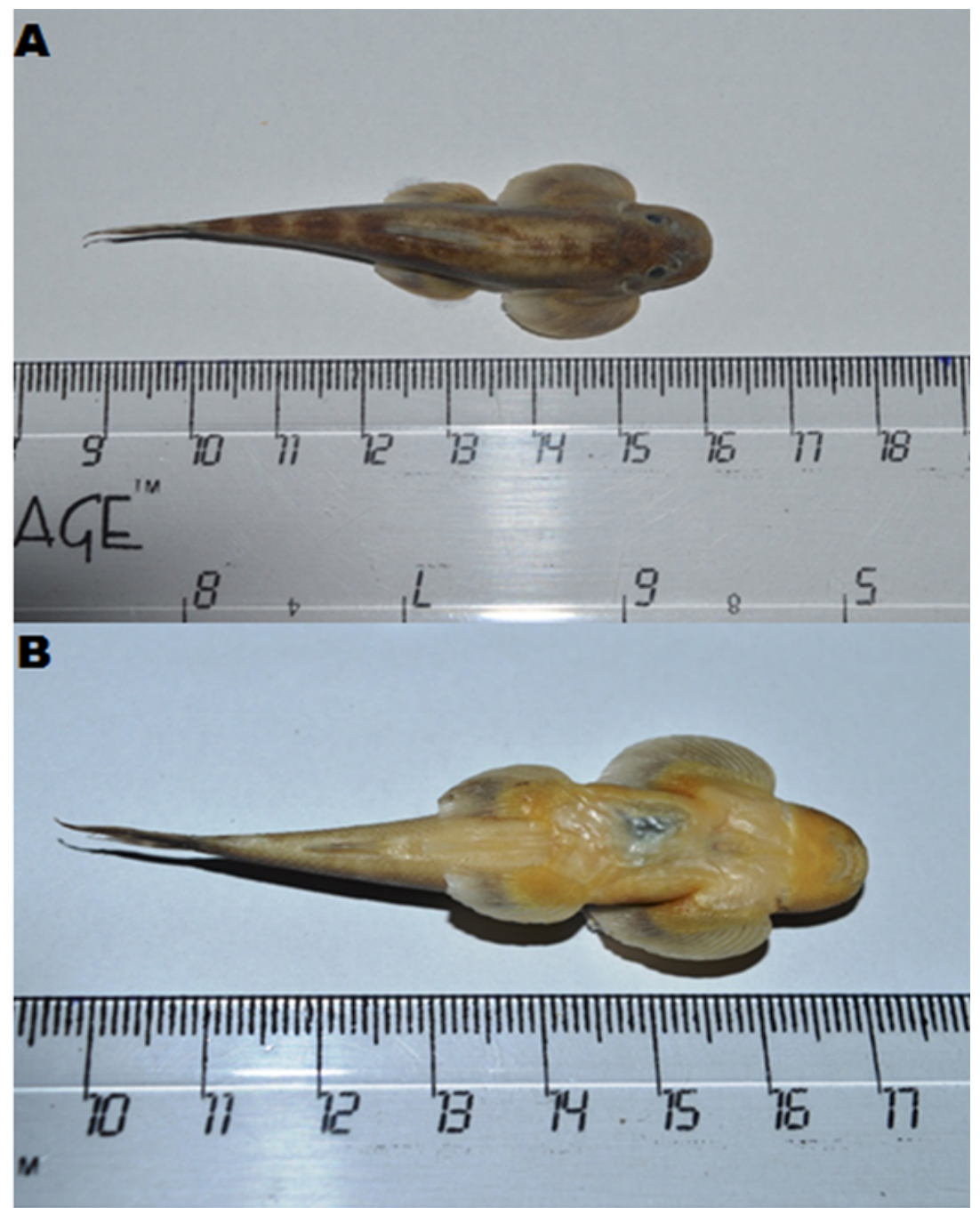

C

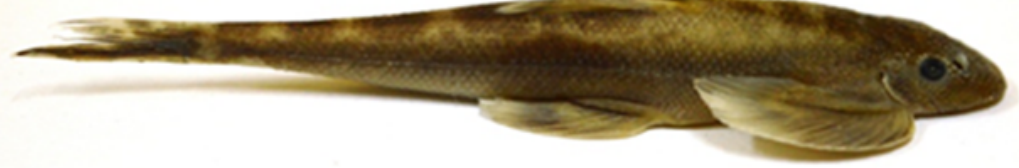

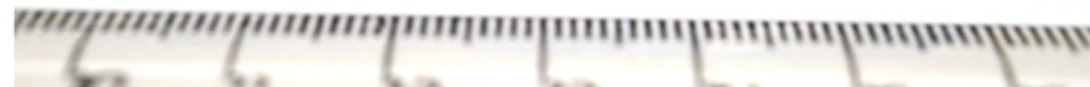
20

Figure 1

A. Dorsal, B. Ventral, and C. Lateral view of Balitora brucei 


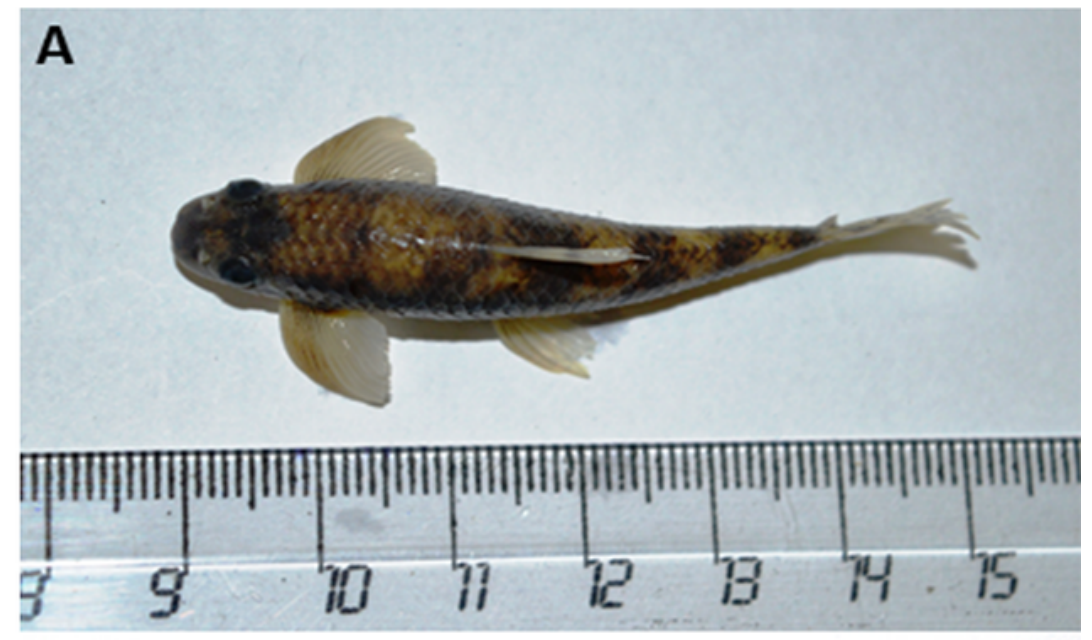

\section{B}
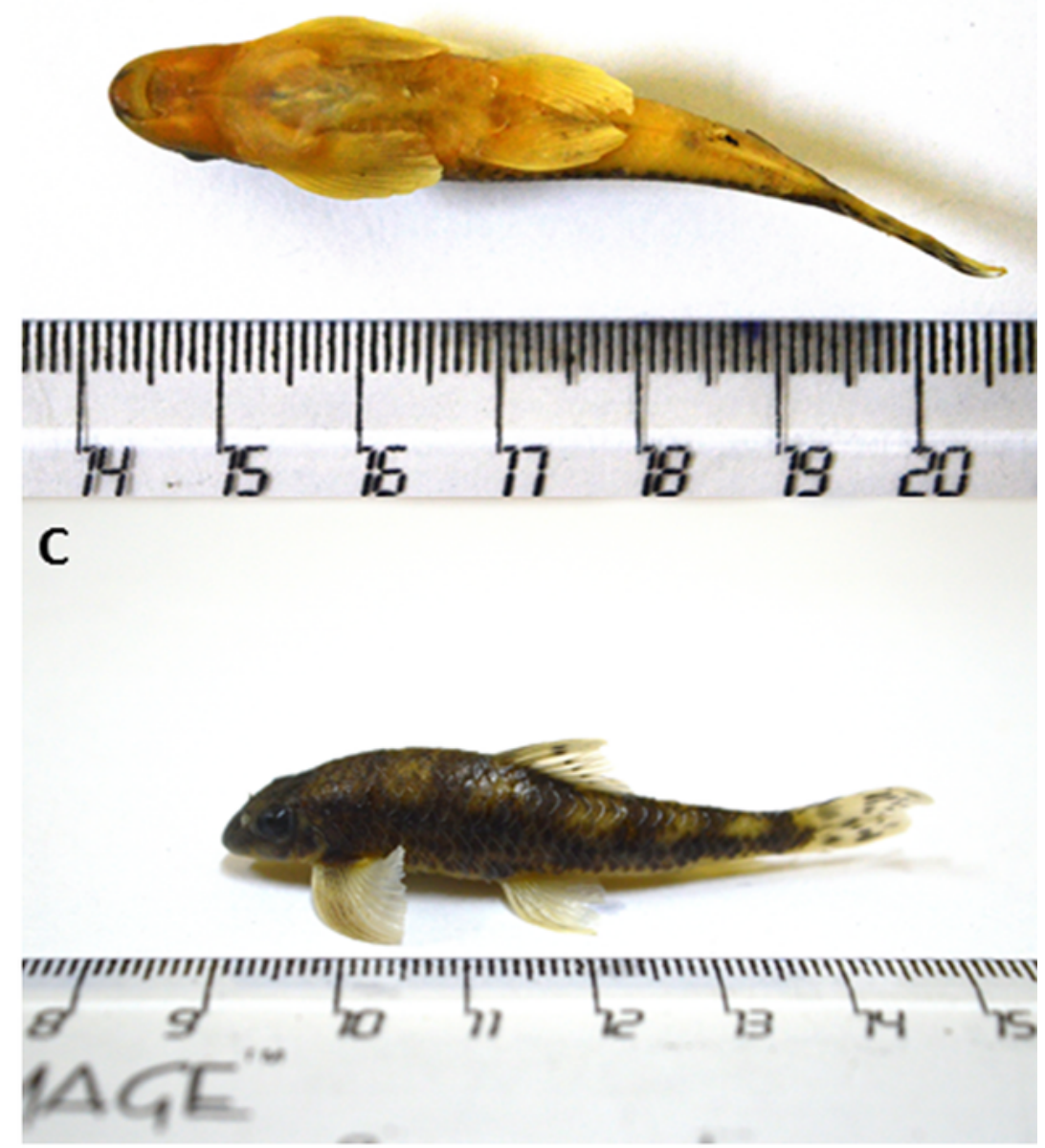

Figure 2

A. Dorsal, B. Ventral, and C. Lateral view of Psilorhynchus balitora 

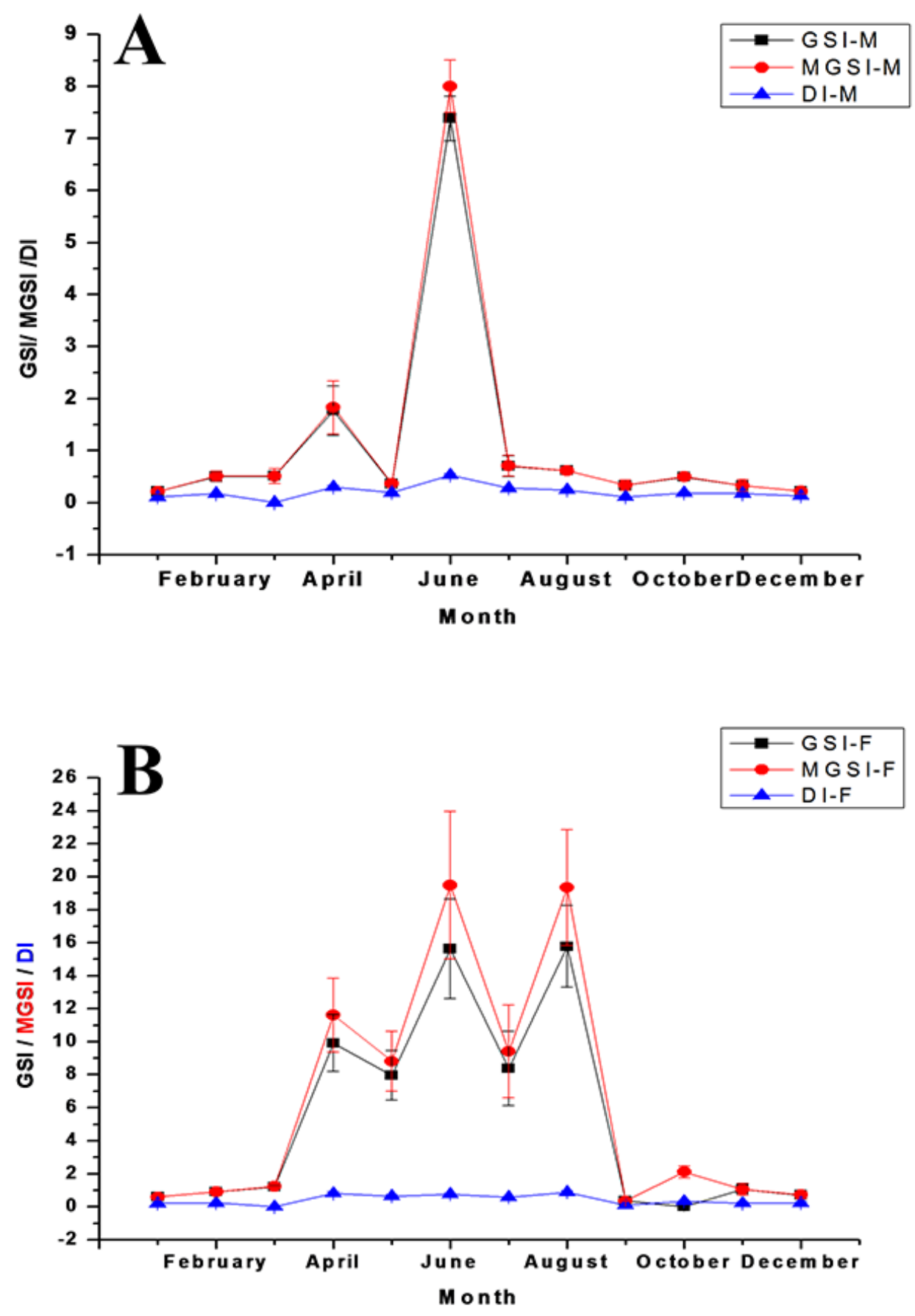

Figure 3

Gonado-somatic index (GSI), Modified Gonado-somatic index (MGSI) and Dobriyal index (DI) of Balitora brucei (a) Male (b) Female 

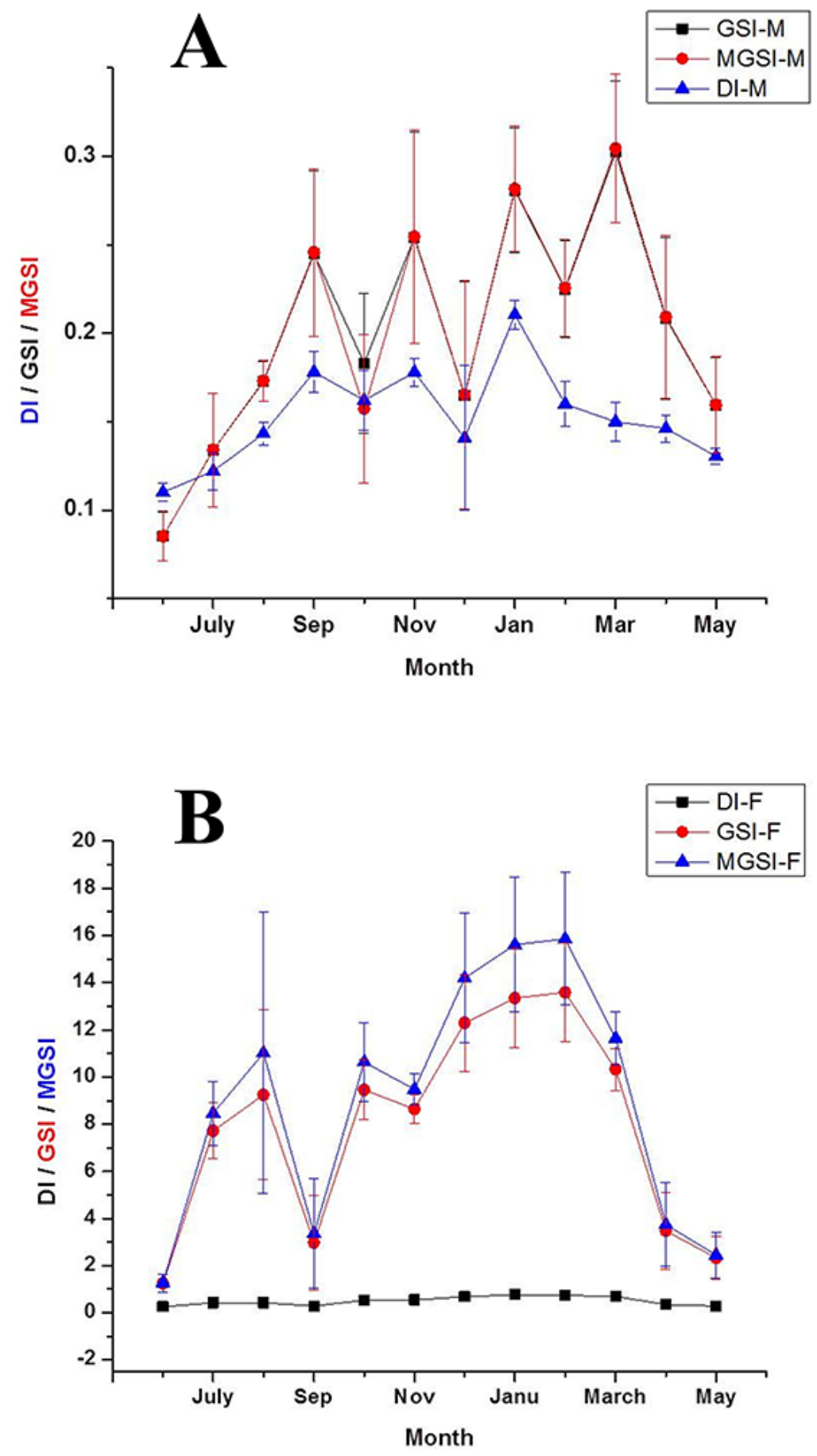

Figure 4

Gonado-somatic index (GSI), Modified Gonado-somatic index (MGSI) and Dobriyal index (DI) of Psilorhynchus balitora (a) Male (b) Female 

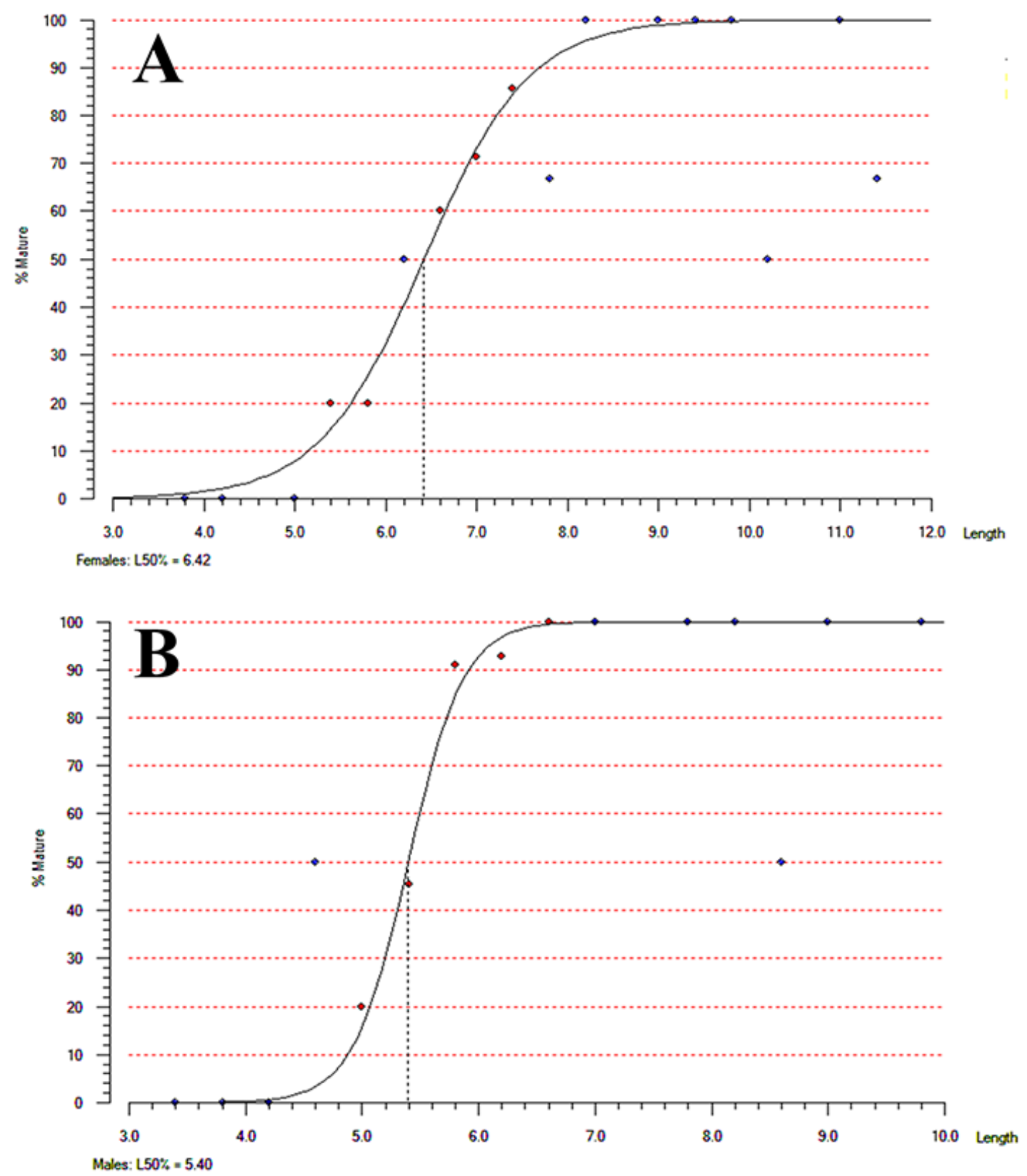

\section{Figure 5}

Size at first sexual maturity of Balitora brucei (a) Female (b) Male 

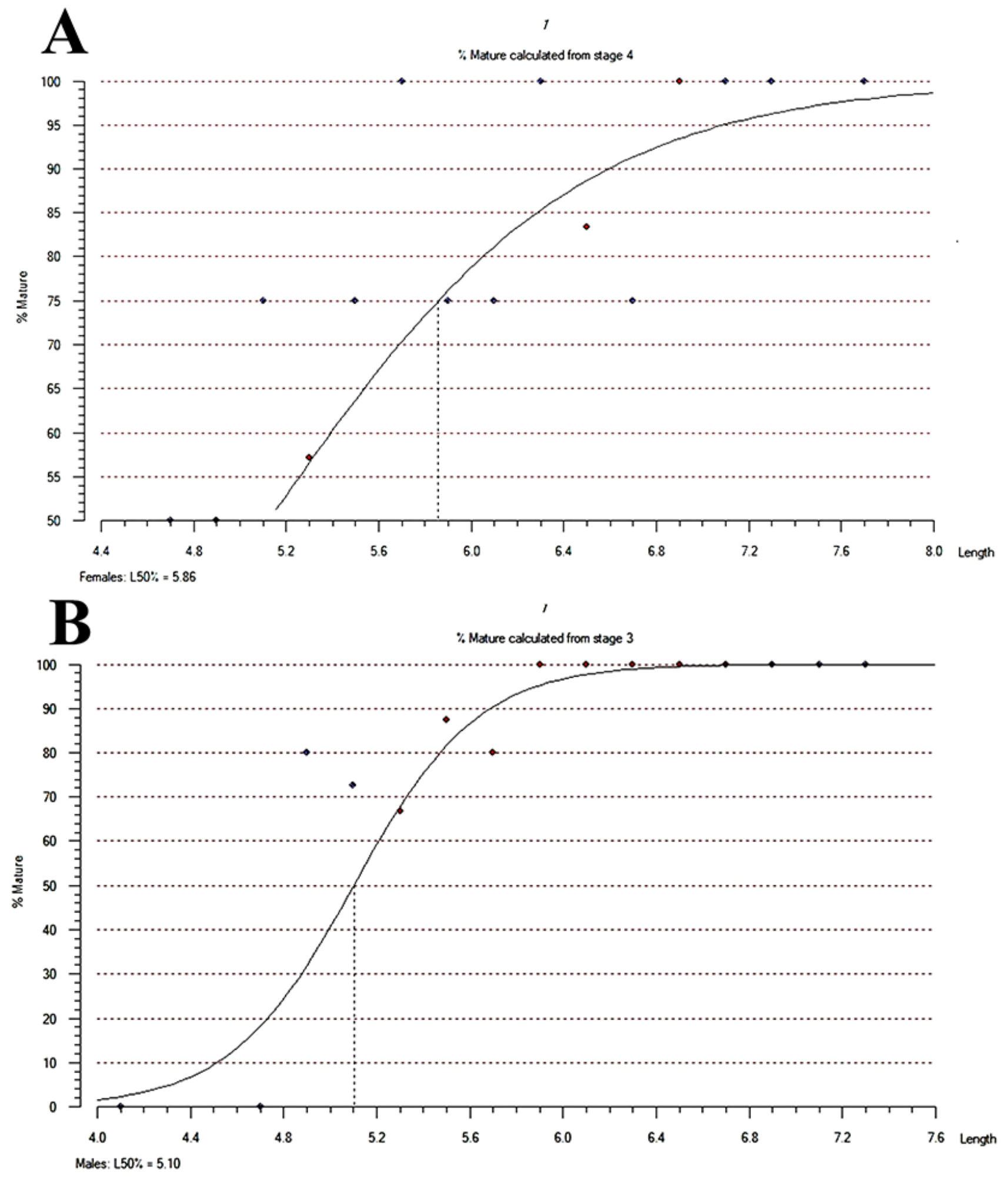

\section{Figure 6}

Size at first sexual maturity of Psilorhynchus balitora (a) Female (b) Male 

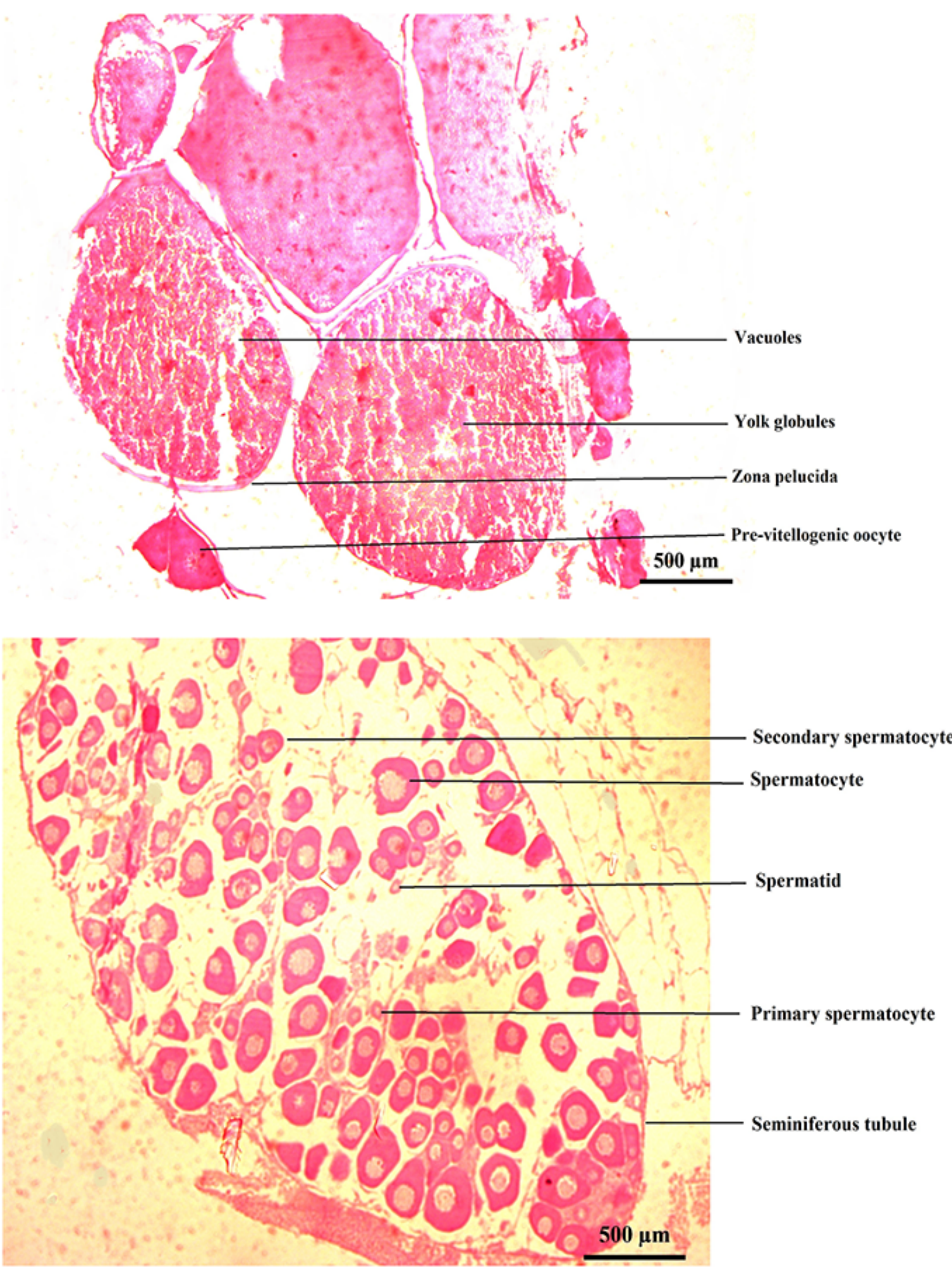

\section{Figure 7}

T.S. of the (A) ovary of B. brucei in 10x (stage IV) and (B) Testis (40x) (Stage III) 


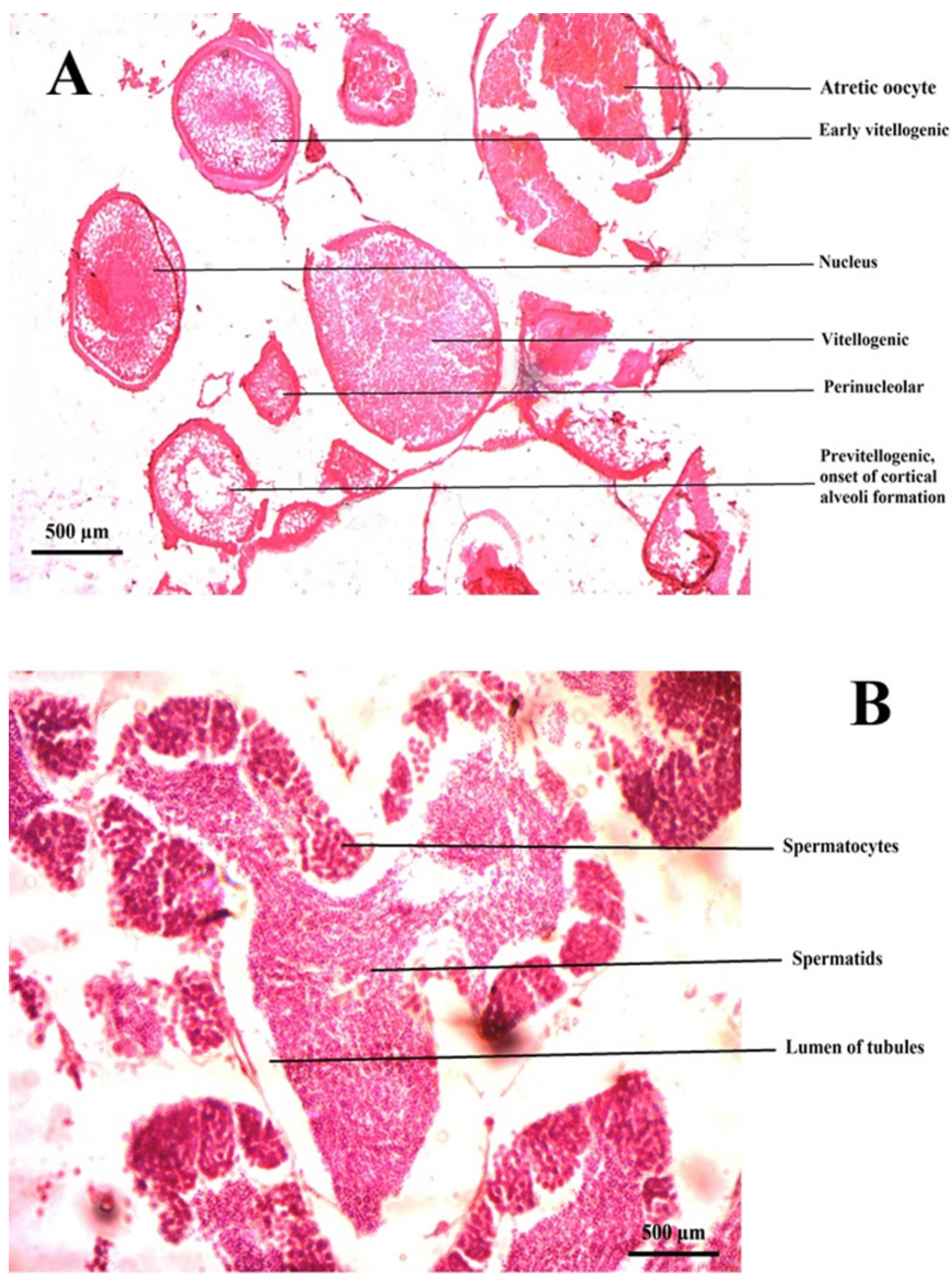

Figure 8

T.S. of the (A) ovary of P. balitora (10x) (Stage IV) and (B) Testis (40x) (Stage III) 